\title{
Elemental Eating: Samoan Public Health \\ and Valuation in Health Promotion
}

\author{
Jessica Hardin \\ and Christina Ting Kwauk
}

Every Samoan has claim to land. There are plenty of mangoes, pawpaws, bananas and breadfruit falling off and rotting on the ground, plenty of fish in the sea. The problem is too many people are coming into town and loathing [sic] around. They are lazy and do not want to go back to their village to work the land. They should stay in their village where their lands are and develop it. (Tuilaepa Aiono Sailele Malielegaoi, quoted in Field 2012)

\begin{abstract}
Comments like these, reported on the Samoan government website, by Tuilaepa Aiono Sailele Malielegaoi, the current prime minister of Sāmoa, are controversial yet predictable. The idea that there is food "rotting on the ground" is an often-repeated lament that suggests that poverty would cease if people worked their plantations. Incidences of cardiometabolic disorders such as diabetes and hypertension, as well as obesity, are often roped into this discussion. The idea is that if people used their land to produce crops, then they would have access to "free" foods that are healthy and have an opportunity for robust physical activity. If people valued agricultural work and the foods they could harvest, then suffering-both in terms of poverty and diseases like diabetes and hypertension-would decline. Prime Minister Malielegaoi presented a compelling logic, one that Samoan public health practitioners have also articulated, but these comments belie contestation over the value of certain kinds of labor and foods.

Public health, as a loosely defined set of partners and organizations, is critical in contouring these food discourses (see Bell, McNaughton, and Salmon 20I I; Guthman 20II). In Sāmoa, from the former public health arm of the government, the Ministry of Health $(\mathrm{MOH})$, to global health
\end{abstract}

The Contemporary Pacific, Volume 3I, Number 2, 38I-4I5

(C) 2019 by University of Hawai'i Press 
and food security organizations with offices in Sāmoa, such as the World Health Organization or the Food and Agriculture Organization (FAO), public health practitioners are engaged in value projects that aim to influence how people make decisions about their diets (see Schoeffel 1984 for more on the history of public health in Sāmoa). These often take the form of education programs that are not neutral but instead create what can become normative health ideologies (Hahn and Inhorn 2008; Farmer and others 20I3). Practitioners themselves are highly aware of their role in creating or attenuating some forms of value. In the offices of the Food and Agriculture Organization, Derek, a high-level agriculture development partner, explained: "I guess the problem has been that local, or, let's say, that traditional foods tend to slide down the scale of preference." Referring to an FAO survey, he told us that what was striking was that "families would almost be ashamed to serve some of the fruits from the backyard." They preferred to buy imported foods "to show status." Derek, who was working on adapting a "Go Local" campaign from the Federated States of Micronesia to the Samoan context, was concerned that the wrong kinds of foods were valued in Sāmoa. He aimed to create value derived from healthiness, local production, freshness, and nutrition rather than from the prestige that he felt was associated with imported foods. Puzzled, he just couldn't understand why local foods were not more highly valued, saying: "There really is no reason, because locally grown foods are definitely a lot fresher. I would suspect a much better quality in terms of freshness and taste attributes than stuff that's been shipped halfway around the world. Weeks on a container ship are not going to help your quality."

While the prime minister was concerned with how he imagined Samoans valued labor, Derek was concerned with how he imagined Samoans valued local foods. He wanted to promote local foods "so that there's a balance. So people don't ostracize certain foods." He thought local perceptions weren't based in any science, which led people to diminish the "unrecognized nutritional qualities" of local fruits and vegetables. "So the idea," he said, "was to investigate and then promote knowledge about nutritional values of indigenous fruits. Because it's not just nutritional value [that matters]. It's also cultural values attached to it." Derek positioned nutritional value- a value he presumed to be neutral and objective-and cultural values-values he assumed were limited to the ways that foods communicate prestige-as in conflict with one another. With such an incongruity established, public health has situated itself with the task of aligning discordant values to create healthful environments. 
Drawing on theories of value, this paper explores how differences between foods are ranked and made meaningful. Elizabeth Ferry has shown that value making occurs on two levels: On the first level is the process of "discriminating between particular objects, ideas, or actions and ranking them within a given system," and on the second level is "the process of deciding what kinds of qualities are worth discriminating and ranking, what differences are meaningful" (2005, I 8-19). In the food representations we examine, both levels are operating at once, encouraging the viewer both to choose foods based on their healthful qualities and to rank these foods as more valuable. As such, we do not focus on "what is valued"; instead, following Daniel Miller, we ask "what value does" (2008, II 22).

Samoan health promotion campaigns aimed to catalyze behavioral change by teaching their audiences to place nutritional value over other values that were categorized as cultural, such as commensality and prestige. Teaching value through these materials created differences through the invocation of scientistic frameworks, discursively producing incommensurability between the sociality of food and the nutritional qualities of food. The primary way this kind of valuing was taught was through the revaluing of local, and sometimes introduced, foods for their nutritional qualities (see also Hobart 20I6a). In this process, indigenous foods were revalued for their elemental contribution to health, thus stripping the foods of their social significance-of their capacity to transform relationships, bodies, land, and communities. In turn, indigenous foods, from coconuts to taro to papaya, were represented as superior foods because of their nutritional qualities, reflecting what Allison Hayes-Conroy and Jessica Hayes-Conroy have called "hegemonic nutrition" (2013). Our focus is on how Samoan public health representations of food-in print and video-valorized indigenous foods based on the logic of nutritional reductionism, thereby encouraging what we call "elemental eating." On the surface, these campaigns attempted to influence how Samoans purchase and cook foods, but when viewed in terms of valuation, it is possible to see that these health promotion campaigns also sought to shift how people relate to food, labor, and the body by doing two things simultaneously: (I) adding fruits and vegetables to the category of "good food" while also (2) including introduced foods that are locally grown (eg, tomatoes, avocados) into a logic of indigeneity.

Flagging these representations of food as valuation opens up theoretical questions about how health is often defined by making commensu- 
rate multiple kinds of value-in this instance, nutritional and cultural. As Heather Paxson pointed out in her study of artisanal cheese in the United States, "the struggle to realize potentially competing values itself constitutes a source of value for producers: it is the moral struggle, and not necessarily its resolution, that makes artisanship worth undertaking" $\left(202_{2}, 8\right)$. Similarly, for those who design health promotion materials, articulating novel food values illustrates a process of foregrounding perceived incommensurability about commensality, reciprocity, and nutrition to forge something new-quite literally, in this case, in the form of a new category of food altogether, mea'ai paleni (balanced food). In what follows, we first contextualize Samoan notions of good food within a wider discussion of the reductive ways that nutritional science elides global food inequalities and the complexity of feeding and eating in Sāmoa. Next, we explore how health promotion knowledge has become normative by drawing from a survey Kwauk conducted. Finally, we show how these health promotion campaigns promote elemental eating as a way to navigate the felt experience of incommensurability between cultural food preferences and nutritional science. We end by reflecting on the consequences of commensuration efforts in health promotion.

\section{Nutritional Reductionism \\ AND INDIVIDUAL RESPONSIBILITY}

Sāmoa, like other Pacific Islands, faces unprecedented rates of obesity and related cardiometabolic disorders, though most regions around the world are seeing similar epidemiological change (Hawley and others 20I4; Finucane and others 20II; NCD Risk Factor Collaboration 20I6). Cultural patterns of eating and food preferences are often foregrounded as primary causes of these rising rates of disease (Keighley and others 2007; Brewis 20I I; see also Hardin, McLennan, and Brewis 20I8). Epidemiological literature tends to explain this emergence as reflecting a shift to imported foods (read: high sodium, high fat, calorie dense, highly processed, "unhealthy") from indigenous foods (read: locally grown, small-scale, "healthy"). However, this idea of a nutrition transition from "traditional," locally produced indigenous foods to new, imported foods has never been as complete or as black-and-white as is popularly represented (see Yates-Doerr 20I5; Manderson 2008). This model often deemphasizes the colonial and neocolonial forces at play in shaping food availability, labor patterns, and migration trends (Fazzino and Loring 
20I3; Howard 20I4, 20I8; Hobart 20I6b, 20I7, 20I8). Island nations such as Sāmoa have been particularly vulnerable in global trade because they have been positioned as small markets, which has led to a steady erosion of their power to protect food security (Plahe, Hawkes, and Ponnamperuma 20I3, 309; Thow and others 20II). In the Pacific, scholarly discussions of the nutrition transition often bring into focus changes in the availability of cheap meat from more industrialized nations located on the Asia-Pacific rim to the Islands-though, globally, health promotion systematically obfuscates such connections (see also Gálvez 20I8; Sanabria 20I6). Fatty meats have become a central symbol for practitioners and publics to explain the rapid emergence of obesity-related diseases (see also Singer 20I4). As Deborah Gewertz and Fred Errington have summarized: "Because the analogies suggested by flaps [sheep bellies] are so clear and vivid - fatty (sheep) flesh makes fatty (Pacific Island) bodies-they become convenient and compelling symbols of what many people see as unequal relationships between whole categories of differently located people-some eating and others eschewing, some becoming rich and others becoming sick" (2010, 3-4; see also 2007; Errington and Gewertz 2008).

There is ever-increasing research that suggests that environmental and epigenetic factors shape risk for obesity and related cardiometabolic disorders, but health promotion in Sāmoa (as elsewhere in the world) persists in rendering health as a moral responsibility (Saldaña-Tejeda and Wade 20I8; Valdez 20I8; Warin and others 20I6; Warin 20I 5; Kirkland 20II; Landecker 200I; Sanabria and Yates-Doerr 20I 5; Hite and others 2010). At the time of our fieldwork in 2OI I-2OI 2, health promotion campaigns in Sāmoa seemed to counter this trend by focusing on creating healthy environments that mobilized communities in the long-term process of achieving institutional visions. The National Health Promotion Policy published in 2010 explains the goal: "All individuals and communities in Samoa are enabled and supported to lead healthier lives through having control over their health and well being [sic], throughout their lifecycle" (Ministry of Health 2010, 9). Yet, official discussions surrounding this policy still emphasized individual responsibility, as was evident when the former Ministry of Health's CEO explained that the health promotion policy of Sāmoa was guided by a "nation-wide collaborative effort in achieving a common goal by encouraging all Samoans to have control over their health" (Ministry of Health 20I0, 2). Despite community-based approaches, the focus on individual behavioral change has persisted, thus 
normalizing the modern project of biomedical citizenship (see Rose and Novas 2005; Anderson 2006; Petryna 2002).

Health promotion materials that center on translating nutritional science into the vernacular for the public often rely on what Emily YatesDoerr has called "nutritional black-boxing," or "the process of consolidating technical and historically contingent ideas about nourishment and the myriad relationships surrounding dietary practices into seemingly unproblematic terms: a vitamin, a nutrient" (2012, 294). This blackboxing is taught through nutrition education in schools and clinics, which elevates the constitutive nutrients of food to a higher value than taste, pleasure, and economy. This reflects a broader effort in nutritional science, public health, and food industries to connect particular nutrients with bodily health and to construct so-called nutritionally balanced diets as a guiding principle for cooking and consumption, or what Gyorgy Scrinis has termed "nutritionism" (2008). However, this process of nutritional reductionism can often obscure more than clarify, as is evident in the fact that, despite persistent nutritional research and public advice, at least in the United States, "people seem increasingly confused about what they are supposed to eat to stay healthy" (Nestle 2007, vii; see also Yates-Doerr 2018, 2019). Nutrition is therefore malleable, which demonstrates that nutrition and diet are cultural constructs that are also historical products. In this sense, nutrition is not only an "empirical set of rules, but also a system of moral measures" (Biltekoff 20I3, 7).

Nutrition advice, cloaked in the language of objectivity and uniformity in describing nutrients, vitamins, and minerals (Porter 1995), is one field of expertise that has helped to create a "new kind of health" (Dumit 20I2) and a "new public health" (Petersen and Lupton 1997), both of which constrict what is considered "normal." This new version of health suggests that "to be normal is to have symptoms and risk factors you should worry about" and that, in turn, gathering knowledge about health is responsible (Dumit 20I2, I). Beyond its capacity to control and racialize populations, public health "as a new morality system" is an organized means of "establishing a set of moral tenets based on such oppositions as healthy/diseased, self/other, controlled/unruly, masculine/feminine, nature/culture, civilized/ grotesque, clean/dirty, inside/outside and rational/emotional" (Petersen and Lupton 1996, xii; see also Montoya 2007; Fee 2006).

The new public health in Sāmoa, as in many other places, is dedicated to the idea that interventions should be culturally appropriate and community empowering. However, culture is considered both a resource and 
a barrier (Hardin 2015). As a resource, fa'asāmoa (the Samoan way) is valued for the guiding principles of respect and generosity that come from deep connections to family, community, and land. As a barrier, health practitioners often bemoan how these values influence priorities in ways that could be detrimental to health. For example, health practitioners would say that Samoans won't ask their families to cook differently to accommodate their new dietary needs or that they will endure uncomfortable symptoms related to unmanaged cardiometabolic disorders in order to avoid burdening the family with difficulties that might arise from visiting the hospital (see Hardin 2019). This dynamic in which culture is both resource and barrier arises in relation to food messaging as well, revealing the malleability of nutrition in how Samoan public health actors attempt to influence health behaviors by changing the value of good food.

\section{The Slipperiness of Good Food}

Good food is both a conceptual tool for analyzing food morals and an explicit category in Sāmoa (see also Weiss 20I3, 20I6). Conceptually, unpacking how Samoan public health practitioners negotiate notions of good food shows that what is considered "good" lies beyond nutritional value and instead points to the ways that food is a vehicle for "providing nourishing care" (Mol, Moser, and Pols 20I0, 2I7). This has long been recognized by indigenous scholars of Oceania-that food and land are inextricably tied to community capacities to provide care and sustenance to humans and nonhumans while also creating "new kinships" (Teaiwa 2007, 206; Goldberg-Hiller and Silva 201 5). ${ }^{1}$ Good food is good because it provides sustenance and an event of caring-a meal served to elders, taro chewed by a mother and fed to a baby. The Samoan category of good food, mea lelei, also suggests an intimate link between staple foods and care. Samoan food is generally split into two basic categories: starches (mea'a'ano) and complementary foods, with the starches-like taro, yams, cassava, green bananas, and breadfruit—serving as the basis of the meal. These foods strengthen the body and are deeply connected to the fanua (land) and the 'aiga (the family) through the labor that produces them. Mea'a'ano require mea lelei as a complement, including imported meat, tinned meat, mea lololo (fatty meat), or the more typical and cheaper option, tinned fish. These dishes can include vegetables, or sometimes are even vegetable based, but the category is about its relation to starches.

Within the last decade, the Ministry of Health has created a new cat- 
egory of food, mea'ai paleni, in an attempt to create value around foods like non-starchy fruits and vegetables. ${ }^{2}$ This category of food, which local and international development agencies have promoted in public health campaigns, is designed to expand what it means to eat a full meal by adding fruits and vegetables to the standard meal of starch and meat or fish. Increasing fruit and vegetable consumption, however, remains difficult for at least two reported reasons. First, fruits and vegetables, especially local varieties, are not associated with the prestige that is linked to the ability to purchase and serve edible commodities. For example, one nurse that Hardin interviewed explained how hard it had been to make changes in her community. As a leader in her church, she was responsible for serving a meal to visiting pastors. Although she wanted to serve local fruits, she was scoffed at by her co-organizers, who insisted on serving corned-beef sandwiches. Serving guests papaya and coconut would have been embarrassing, indicating to the guests the host's inability to purchase what they considered better foods from the store, like bread, butter, and tinned meat. In Hardin's household, that of a matai (titled family leader) and orator, when another matai would arrive unannounced to discuss family matters or make a request for a fa'alavelave (events organized around major life events), one of the children would run to the village store to purchase soda, bread, and butter to serve the visitor. These were appropriate foods for a visitor, while the taro, breadfruit, and bananas that were always available were not.

Health professionals we spoke with, including physicians and high-level administrators, thought most Samoans felt vegetables were considered empty and tasteless, while fruits were considered children's food or even pig food. One physician said: "The problem here in Sāmoa is vegetables have never been an important part of the diet. Vegetables and fruits are just filling, to just fill your belly. It's not food. The kids will eat mangos in the mango season until they are sick 'cause they're hungry, but it is not regarded as food. It's not part of your healthy diet or well-being. It's just [to] stuff your stomach until you can get a decent meal." In our own households, fruits were consumed occasionally by adults throughout the day but usually not during meals, unless there was no other food available. In times before paychecks were cashed, or times when food was sent elsewhere as gifts, families often made supo esi or supo fa' $i$ - soups made from coconut cream and papayas or bananas. Ingredients for these soups, like starches, were nearly always available from plantations or fruit trees near the family house. These were therefore "free" foods, but they were 
also considered light meals that, while able to satisfy the need for a meal, sometimes left one feeling hungry. Additionally, fruits and vegetables were often associated with the imported variety, including cabbage, lettuce, tomatoes, and apples, which most highlighted as expensive and unable to leave a person sated (see Hardin and Kwauk 2015).

In this context, we became curious about the potential disconnect between everyday references to good food (preferred foods to eat) and public health renderings of good food (nutritious foods one should eat). Kwauk conducted a large-scale grounded survey among 760 secondaryschool students and youth between the ages of fifteen and thirty-nine in Savai'i (Sāmoa's large rural island) and 'Upolu (the main island) to explore the relationship between competing notions of good food (see also Choy and others 2017; Farrell and others 2019). ${ }^{3}$ Survey results suggest that Samoans' supposed transition from a diet composed of traditional foods to a diet composed of new, imported, and unhealthy foods is not as unconscious a process as popular understandings imply. For instance, over half of the survey participants listed at least one starchy food as a favorite food, ${ }^{4}$ and nearly half listed at least one fruit or vegetable as a favorite. ${ }^{5}$ In contrast, less than a quarter of the participants named protein foods as favorites. ${ }^{6}$ Tinned meats like pisūpo (corned beef), fasipovimāsima (corned beef or salted beef), and elegi (canned mackerel)—foods circulated in public discourse as favored foods in Sāmoa-ranked at the bottom of the listed proteins.

The survey also inquired about junk foods, including popular snacks like locally made panikeke (fried dough) and imported instant noodles and chips (see also Errington, Fujikura, and Gewertz 20I2, 20I3). Notably, these foods were only cited by about I percent of participants surveyed. While this data suggests a dislike of snack foods, public health officials tend to present a different picture. One public health worker, who worked with schools, said: "For school children, the biggest challenge is the changing lifestyle. The kids nowadays are more modernized, and they tend to eat the processed foods. Like, we try and we try, that's why now we're trying to educate their families to eat locally." This person was part of a special team assembled to address new guidelines for school canteens. Her discussion of the difficulties of implementing the new guidelines is worth quoting at length:

A lot of the canteen owners were prepared to make changes, to sell healthy food, but there were many complaints from them and from others that the 
children simply won't eat it. The canteen owners feel they are making a loss, so making change is not going to be easy. The schools can enforce the rules, but if the kids buy Twisties [Fijian-made snack foods similar to Cheetos] in the shop next door, they are not allowed to eat them in the schools. So there's a whole-so it's quite a complex issue. There are certainly instances where children are embarrassed to eat local foods, so you know even if the bananas are there, or I know from my own experience more than once that parents have said that they try to get their children to take bananas to school but they are too embarrassed. So it's a whole attitude; it's the environment.

Public health practitioners frequently articulated to us their concern that food preferences were often shaped by associations with wealth and cash poverty. This survey data counters these perceptions of the popularity of and high value given to imported food commodities. In general, the respondents' low reference to foods otherwise considered good foods (eg, corned beef, salted beef, snack foods) points to a larger inconsistency within popular discourse, which claims-often with much zeal-that Samoans like to eat fatty meat and snack foods. These reported preferences suggest not that Samoans demonstrably prefer what are considered healthier foods but instead that there is a working knowledge of health promotion-based notions of good food, reflecting what Linda Garro has called "official accounts" that convey "conventional teachings from health promotion." That is, these results provide insight into "health as talk (directed at researchers)" and not "health as enacted" (Garro 20I0, 472). Thus, what can be discerned from these results is that at least secondary-school students in Sāmoa were indeed aware of what food types were generally considered unhealthy (eg, Twisties, soda, pisūpo) and should be consumed less-or at least not reported on a survey as one's favorite food-and what foods should be preferred (eg, fruits, vegetables, fish, chicken).

\section{Elemental EATing}

One way that healthy eating has been communicated to the Samoan medical public (ie, those Samoans who are engaged with medicine and who visit hospitals and clinics) is through health promotion posters. Various posters sponsored by the Secretariat of the Pacific Community, the Samoan Ministry of Health, and the World Health Organization have been widely visible across government offices, shops, and medical facilities. The posters encourage the audience to see food differently by thinking of it as made 
of constitutive elements such as fat, nutrients, and sugar. These elements are implicitly categorized as good (eg, nutrients, lean meat) or bad (eg, fat, sugar). The logic is supposed to be easy: "With the input and output established, what more is there to know?" (Yates-Doerr 20I2, 294). These public health representations are meant to shape food choices by cultivating elemental thinking and practice, which is a kind of valuation in that this framing encourages viewers to weigh the values of constitutive parts of food. Viewers are expected to relearn how to choose foods based on nutritional values and to rank these foods as more valuable than other foods that are typically valued for other reasons. Posters tend to fall into three categories: images converting common foods into corresponding spoonfuls of sugar or fat, food diagrams, and demonstrative cooking materials focused on eliminating salt and fat.

In the first set of posters, common foods like fried fish, taro, coconut cream, and chips are converted into spoonfuls of fat. For example, a can of non-diet soda is equivalent to eight teaspoons of sugar (see figure I), and a fried fish fillet is equivalent to nine teaspoons of fat (see figure 2). Notably, a plate of three pieces of boiled taro is equivalent to zero teaspoons of fat (see figure 3). This is similar to a New York City anti-obesity campaign poster in which "soda being poured from a bottle to a glass turns into grotesquely represented human body fat, followed by the advisory message: 'Don't drink yourself fat'” (Rubin and Joseph 20I3, 206). While the American example fosters weight stigma, the Samoan posters isolate decontextualized ingredients as bad. In these kinds of posters, the viewer is taught how to break down desirable foods into undesirable constitutive parts. Sugar and fat in these cases are negative nutrients, or nutrients deemed to have no nutritional value and therefore considered to be of questionable moral value.

Elemental thinking works in the opposite direction as well. For example, in a poster titled "Eat Less of These Foods for Good Health" (and its Samoan-language counterpart), food categories are based on fat, sugar, and salt content (see figures 4 and 5). In the photos that accompany each category, there is a mix of local foods that are widely consumed, like pe'epe'e (coconut cream), and foods that are not as widely consumed, like margarine. Here, consumers are introduced to new groups of food based on the most important ingredients: fat, sugar, and salt. This highlighting of single ingredients is also evident in the мон campaign "Slash da Salt." During its run, banners were mounted outside the мон offices, and popular exercise groups wore matching T-shirts at annual health events, further 


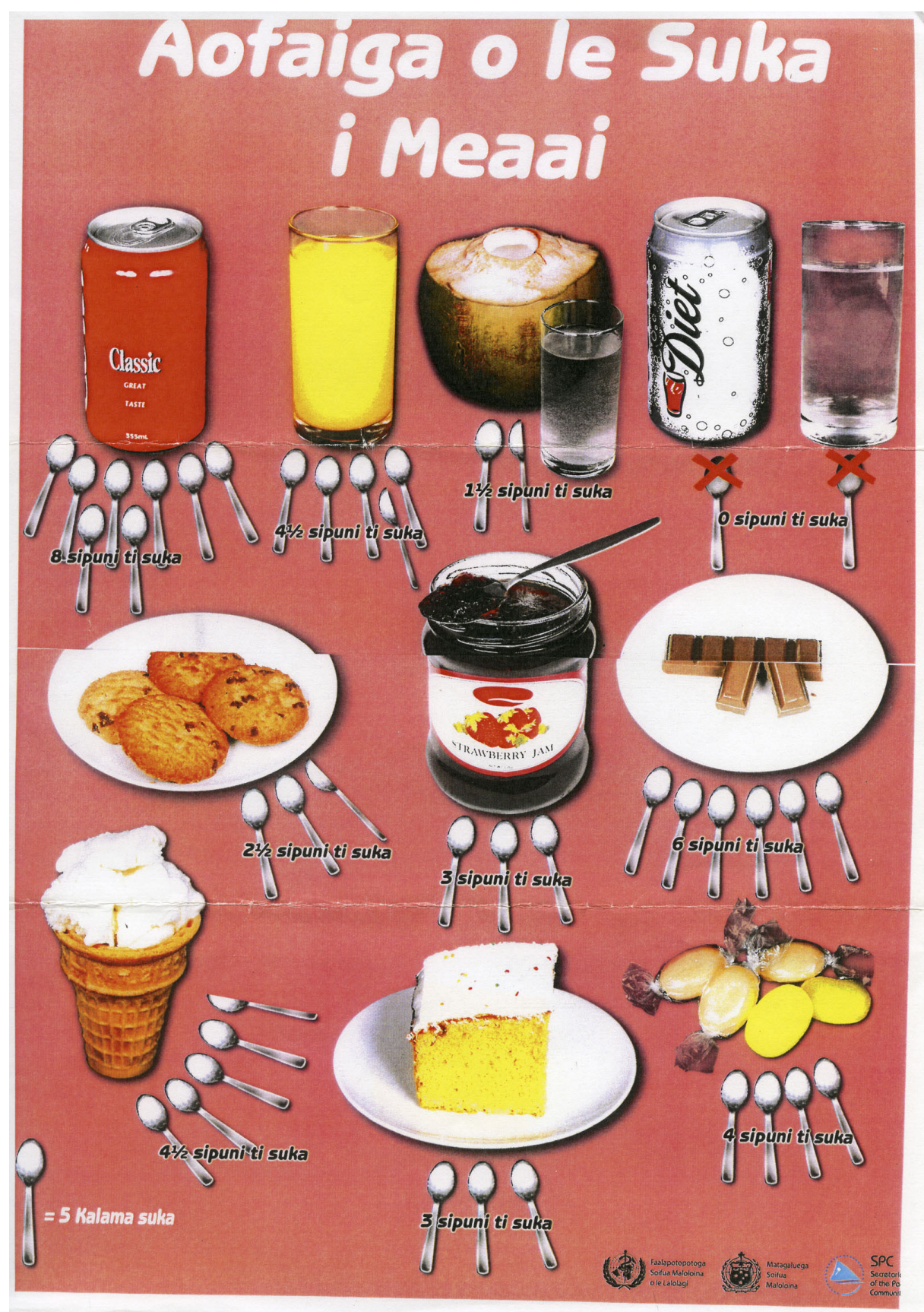

Figure I Aofaiga o le suka i meaai (Amount of sugar in food). Poster sponsored by the World Health Organization, the Samoan Ministry of Health, and the Secretariat of the Pacific Community. 


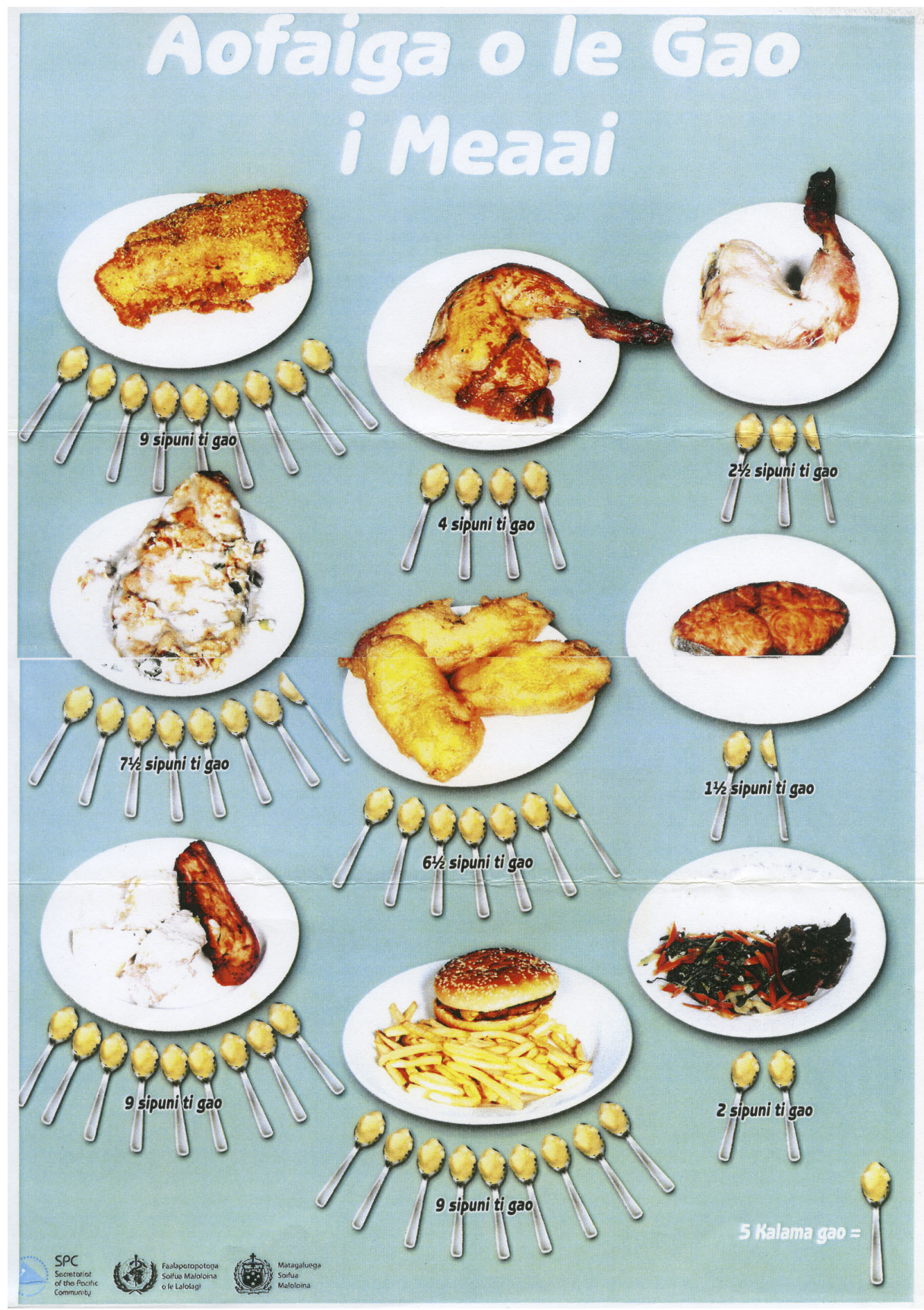

FIgure 2 Aofaiga o le gao is meaai (Amount of fat in food). Poster sponsored by the Secretariat of the Pacific Community, the World Health Organization, and the Samoan Ministry of Health. 


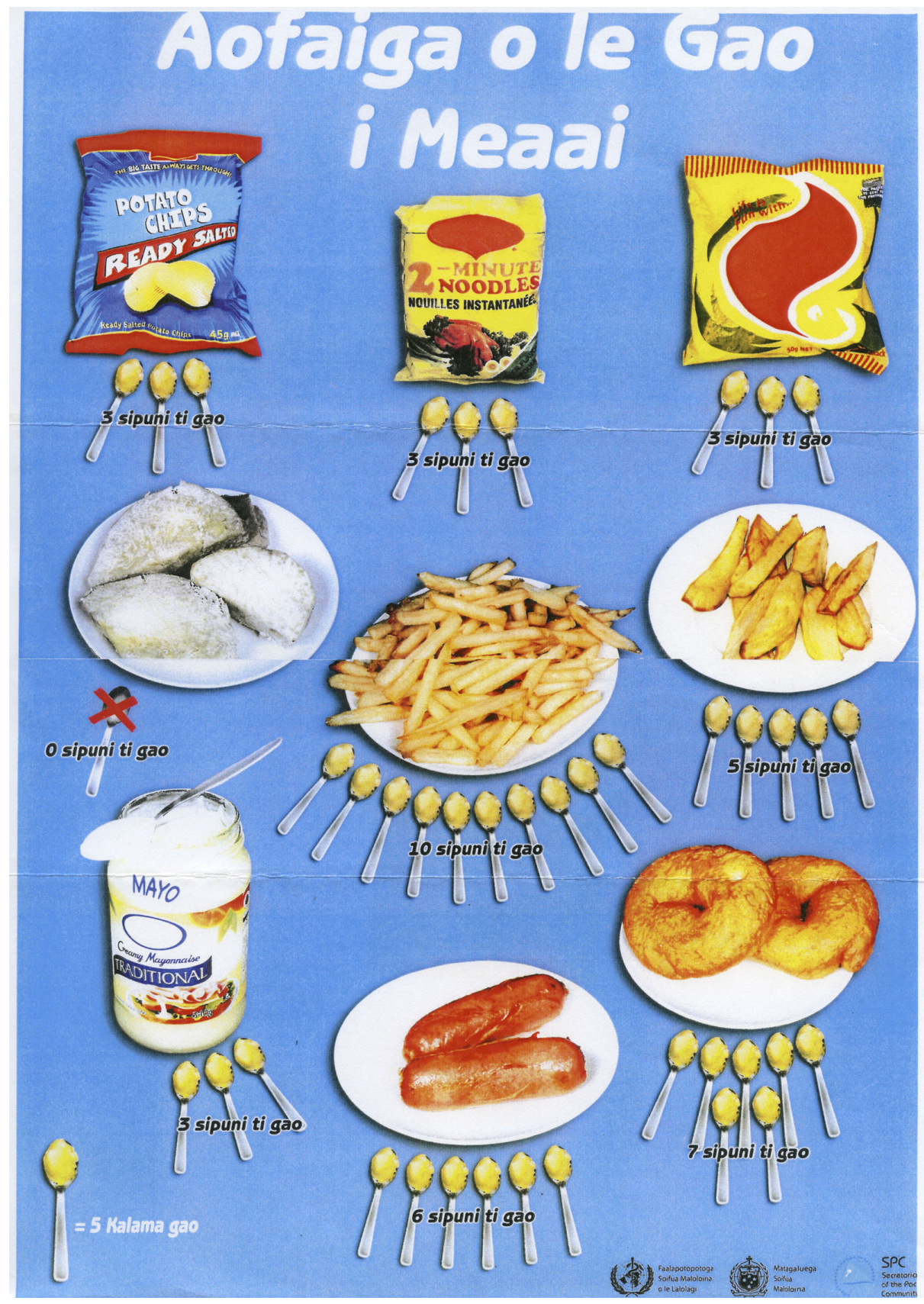

Figure 3 Aofaiga o le gao is meaai (Amount of fat in food). Poster sponsored by the World Health Organization, the Samoan Ministry of Health, and the Secretariat of the Pacific Community. 
entrenching the negative-nutrient idea that salt consumption is counter to healthy living.

Beyond creating negative nutrients, other posters have featured new food categories: foods for good health (fruits and vegetables), body building (protein), and energy (starches). In one poster, printed as a public service announcement, the first two categories are represented by photos of foods that are not specific to Sāmoa (ie, mushrooms, peaches, grapes, and salmon). Yet, the accompanying message directs the reader to "eat plenty of Samoan vegetables and fresh fruits daily." Here the message counters the image that might reify the widely circulating association of imported fruits and vegetables with high expense. Also, reiterating the value of "Samoan grown starchy food," the message values local foods because they are "simply the best for healthy energy." Embedded in this approach to recategorization is the suggestion that food values should be predicated on nutrition.

Based on the idea of reducing foods to elements, demonstrative posters have been widely available as well. In these posters, the steps focus on making foods deemed unhealthy or bad because of their fat content into healthier options through elemental cooking (see figures 6-8). Step one in each of these posters gives methods for removing fat. For unprepared meats, the instruction is to remove "visible fat," while for tinned meats, the instructions suggest boiling the can and then draining the excess fat. Each poster teaches the viewer to see fat as trash (eg, step two in making healthier mutton flaps is to "throw fat away"). Fat is therefore not only a negative nutrient but also waste. These posters also call for the addition of "lots of colored vegetables" to "staple foods, such as taro or green banana," the goal being to enhance meat and starch meals with added nutrients in the form of vegetables not ordinarily considered necessary for a satisfactory meal. It is worth noting that, while cuts of a pig, cow, or sheep are divided and distributed during ritualized exchange in an elemental fashion, these posters encourage valuing foods for their nutritional components rather than for their role in building social relationships (see also Nihill 200I; Linnekin I99I; Young I97I; Kahn I986; Schram 20I 8). The kind of cooking-as-conceptualizing illustrated in the posters renders fat as excess or waste, not as a valued element-although fat is precisely what makes these meats valuable as (delicious) gifts. The added value is instead derived from the vegetables because of their health-giving qualities. The targeted problem is not the food itself but rather the ways food 


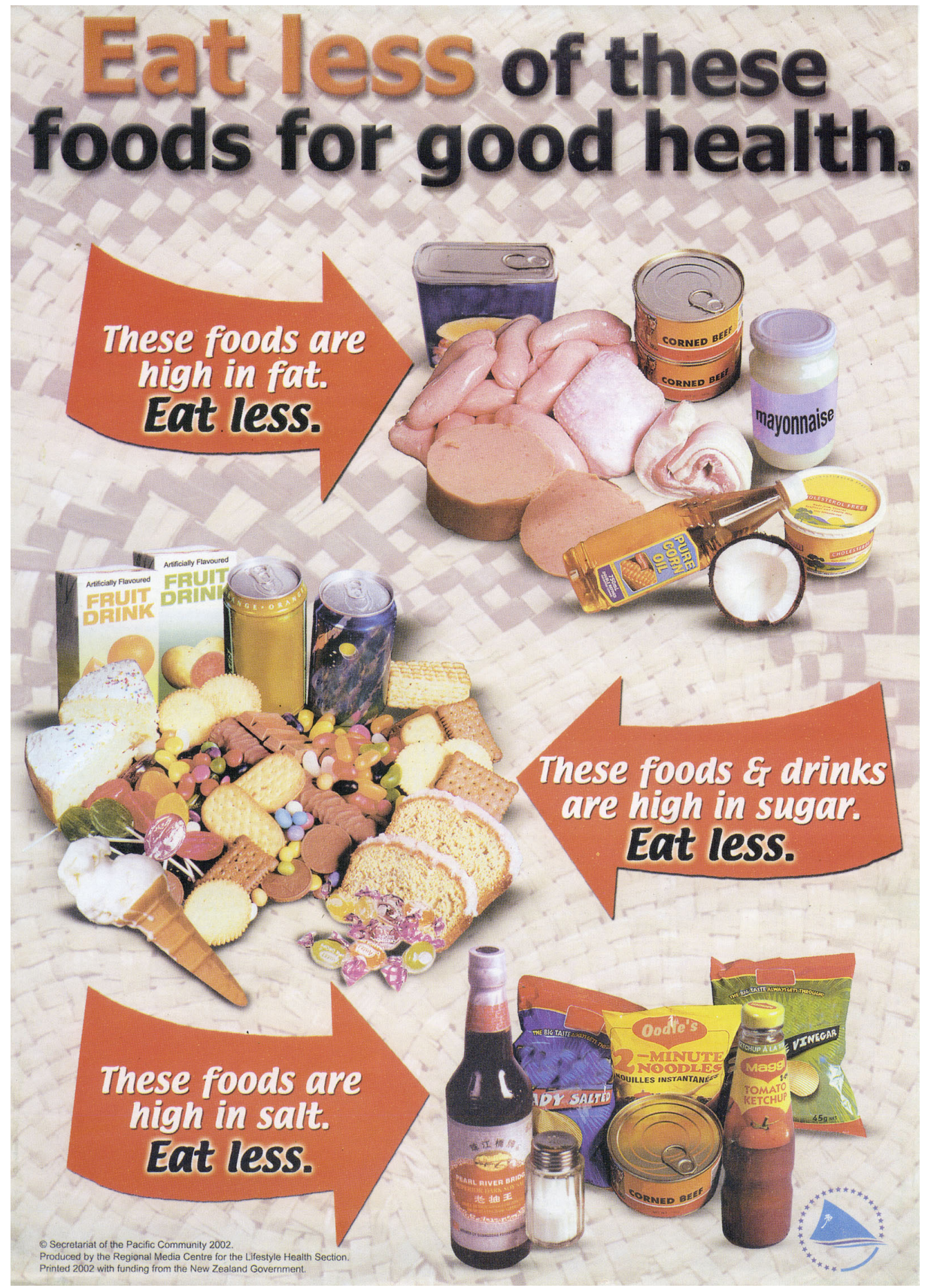

FIgure 4 Eat Less of These Foods for Good Health. Poster sponsored by the Secretariat of the Pacific Community, 2002. 


\section{Fa'aitiitia le taumafa i mea'ai nei mo lou soifua mälölöina}

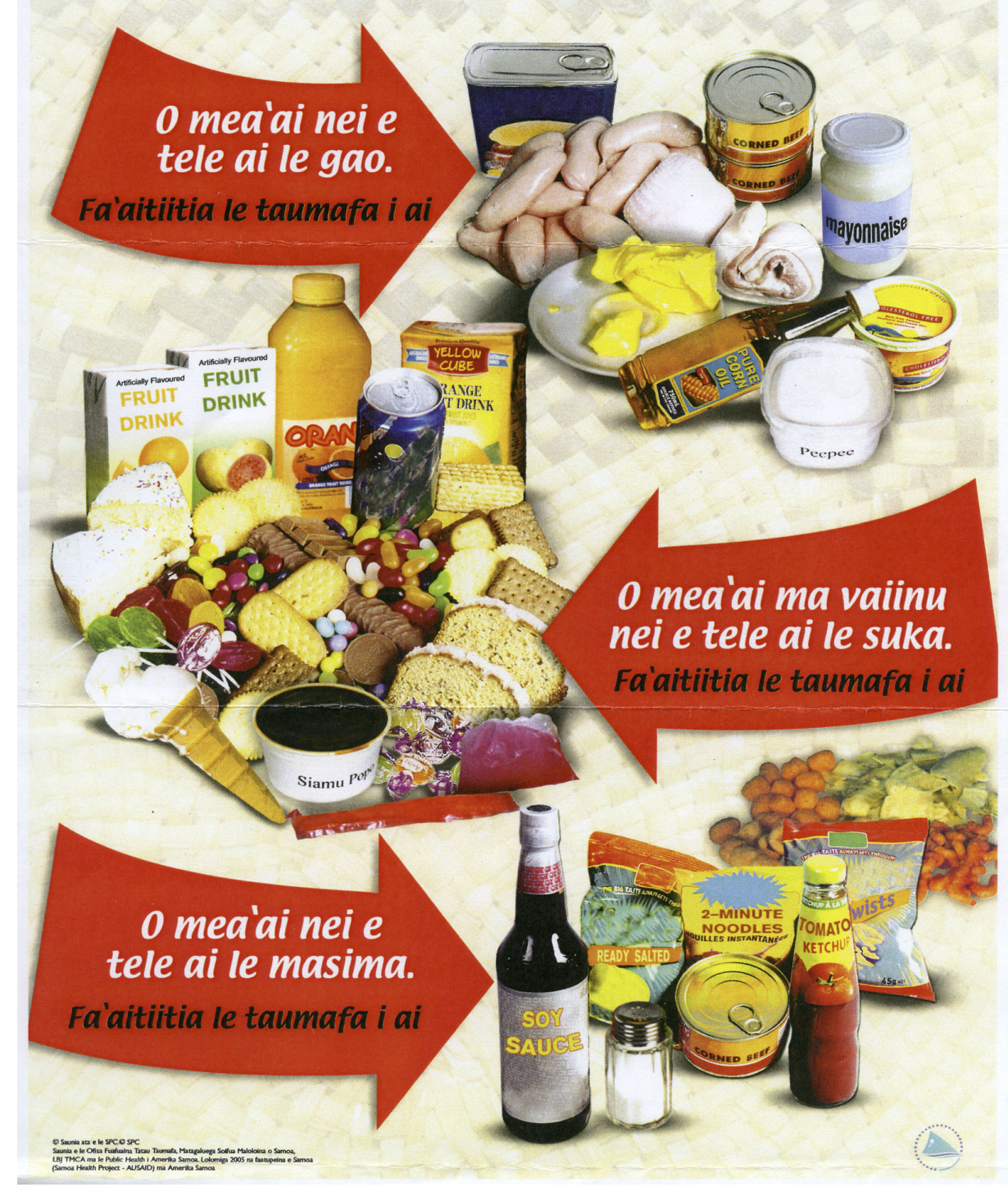

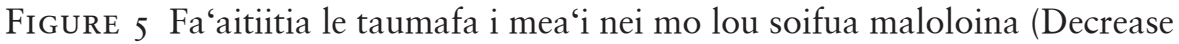
your consumption of these types of food for your health). Poster sponsored by the Secretariat of the Pacific Community, 2005. 
is conceptualized as part of the "healthier" (read: nutritious) meal. The viewer is thus encouraged to think about food in terms of its invisible elemental parts and change behaviors as a result.

Public health messaging also crosses over into agricultural development through posters designed to diversify diets and agricultural production, such as those featured in a poster display by the nutritionists working at the Ministry of Health during the 20I I agricultural fair just outside Apia. The Ministry of Health presented the poster "Grow and Eat Dark Green Leafy Vegetables" to encourage those with plantations to grow more varieties of edible green vegetables and to educate farmers on the edible greens potentially already growing on their land. These edible greens are local but not always recognized as food. In fact, Hardin's adopted sister often teased her about eating "only leaves" when she ate these varieties of greens, insisting that she must be hungry all the time as a result. Another poster in the display, titled "Easy and Cheap Foods," placed greens and breast milk in the same category-foods that were free and thus easy to access. Its diagrams also showed the nutrient, vitamin, and negative-nutrient content of taro, coconuts, bananas, and banana chips. The assumption of the poster display, and the presence of health officials at an agricultural fair, was that knowledge of nutrition and knowledge of plant species were interconnected and imperative to health. Representing nutritional value while recognizing cost was imagined to be a persuasive way to encourage farmers to grow and eat differently. We have detailed the categorical work that these posters were designed to accomplish to show how nutritional value and other competing cultural values around sociality were made incommensurate; they were separated, and the viewer learned to value nutrition over other competing values.

\section{Clowning Scientistic Verification}

Public health messaging in Sāmoa has been directed toward changing food values-from prestige values based in wealth-fat-salt to nutrition values based in freshness-localness-healthiness. Through media campaigns, and in particular a series of health promotion videos designed for television, the Ministry of Health has sought to convert non-meal edibles (such as fruits and vegetables) into required daily nutrition, effectively moving these foods into a new category, mea'ai paleni. In one video in particular, the message focuses on consumption for health by extending indigenous ideas about power, strength, and potency from starchy foods to fruits and 


\section{Making a healthier meal using Povi/Pulu Masima \& Brisket}
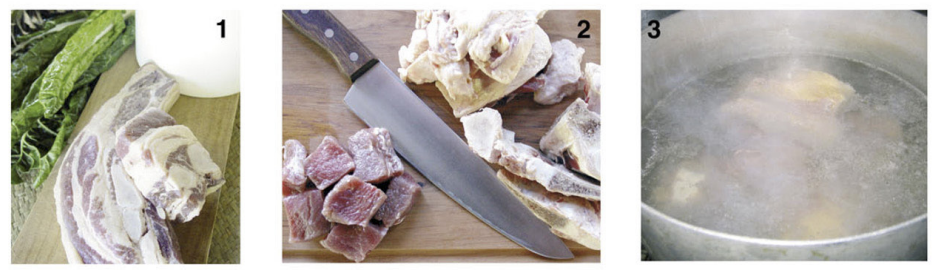

Cut off the visible fat - Boil meat until cooked, changing the water two or

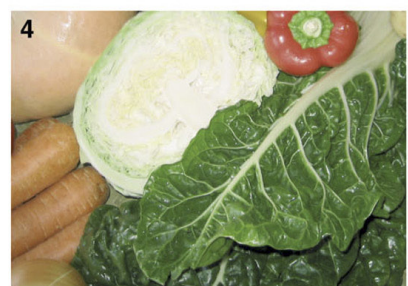
three times during cooking

Serve with lots of coloured vegetables, taro or green banana

\section{Alternatively, use the leaner cut of corned silverside shown below}
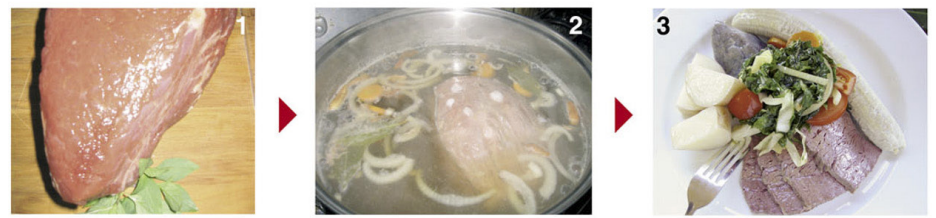

Boil the meat until cooked. Serve with lots of coloured vegetables and taro, potato or green banana

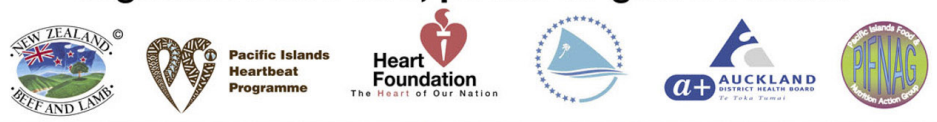

Figure 6 Making a Healthier Meal Using Povi/Pulu Masima \& Brisket. Poster sponsored by New Zealand Beef and Lamb, the Pacific Islands Heartbeat Programme, the Heart Foundation, the Secretariat of the Pacific Community, the Auckland District Health Board, and the Pacific Islands Food and Nutrition Action Group, August 2004. 


\section{Making a healthier meal using mutton flaps}

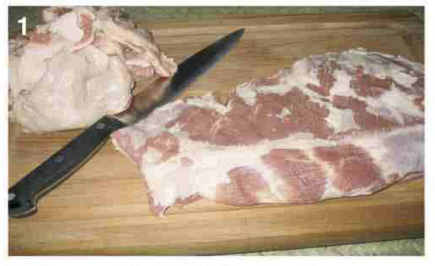

Trim all visible fat

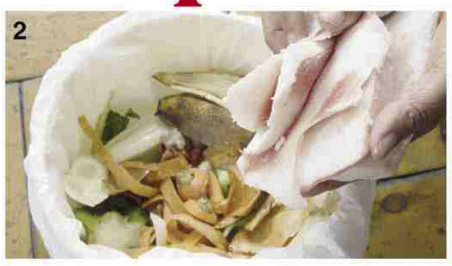

Throw fat away
Prepare vegetables and trimmed flaps

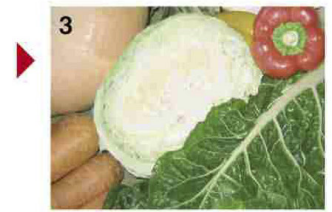

Boil meat until tender. Add lots of coloured vegetables and boil until cooked
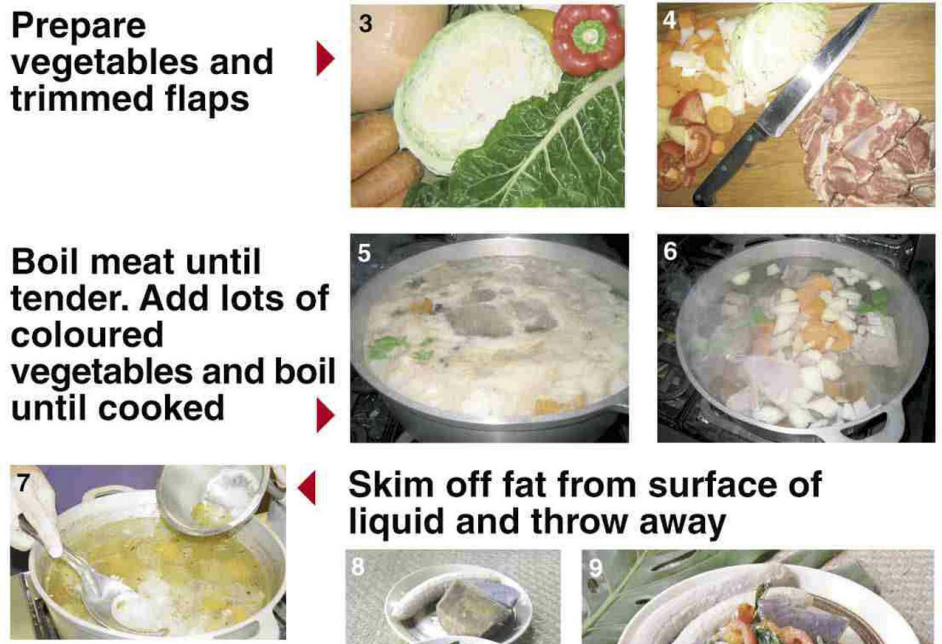

Serve with staple foods, such as taro or green banana
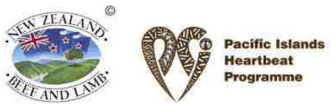

Skim off fat from surface of liquid and throw away
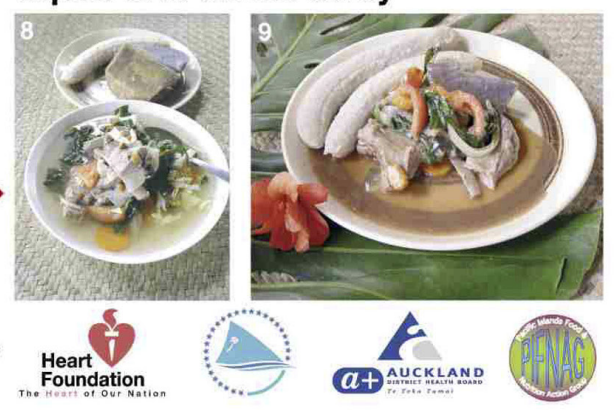

Figure 7 Making a Healthier Meal Using Mutton Flaps. Poster sponsored by New Zealand Beef and Lamb, the Pacific Islands Heartbeat Programme, the Heart Foundation, the Secretariat of the Pacific Community, the Auckland District Health Board, and the Pacific Islands Food and Nutrition Action Group, August 2004. 


\section{Making a \\ healthier meal using corned beef}

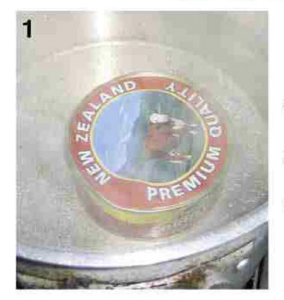

Warm corned beef by heating can in hot water or by warming contents in a pan

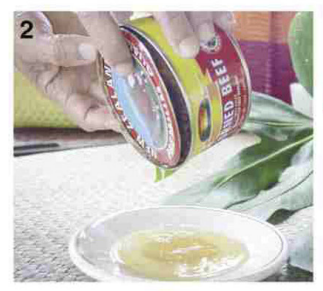

1 Drain off fat. Throw fat away

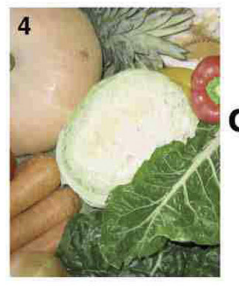

$$
\begin{aligned}
& \text { Add plenty of } \\
& \text { vegetables to } \\
& \text { drained corned } \\
& \text { beef and heat } \\
& \text { until cooked } \\
& \text { through }
\end{aligned}
$$

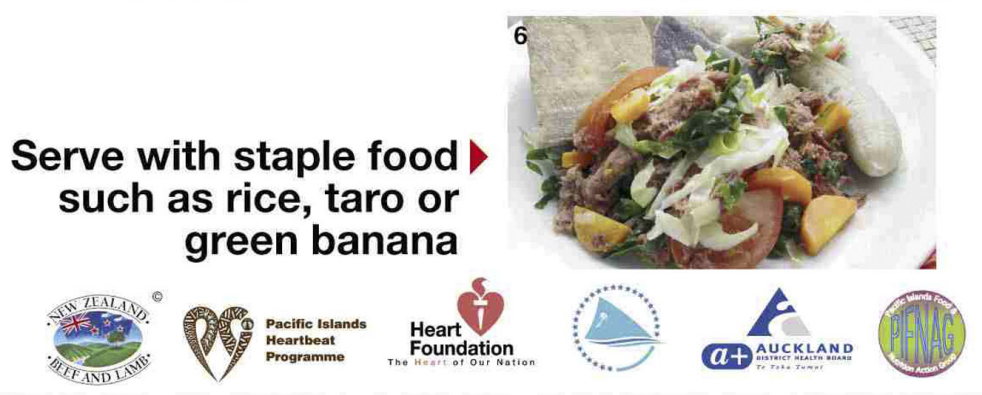

Figure 8 Making a Healthier Meal Using Corned Beef. Poster sponsored by New Zealand Beef and Lamb, the Pacific Islands Heartbeat Programme, the Heart Foundation, the Secretariat of the Pacific Community, the Auckland District Health Board, and the Pacific Islands Food and Nutrition Action Group, August 2004 . 
vegetables. The minute-long video was filmed in the vegetable market in Apia. The main character, who is styled as a Samoan scientist, leads a group of youth through the market, which is empty of its daily traffic. As the scientist raps, the youth learn to value indigenous and local foods for their nutritional qualities. The video ends with a choreographed dance, common to Samoan youth activities.

Central to the translation of non-meal edible items into required daily nutrition is the role of authoritative science. The main character in the video wears a white lab coat, carries a clipboard, and wears thickrimmed glasses. However, this scientist is also clearly Samoan: His lab coat is painted with geometric patterns across the shoulder, and he wears a carved fishhook pendant around his neck. Drawing on a tradition of clowning, the protagonist is part scientist, part clown, which is indexed by his bushy green hair and large orange and yellow pen (see also Mitchell I992; Hereniko I995, I999; Sinavaiana I992). He opens the video by rapping in Samoan the directive "Children, listen here, eat balanced foods." As he consults his clipboard, the camera pans down to a market table filled with fruits and vegetables and then focuses on a basket with coconuts and a large sign with the word "masima" (salt) on it. "How can you be healthy?" he asks, responding, "The answer is to eat balanced foods but [also] cut the salt," as a large red X appears on the salt sign. He consults his clipboard again and offers, "Advice for the young children, sugar is not good. It is therefore important to cut it," as a red $X$ appears on the hands of a young boy who is sipping a can of soda. He then takes the soda and swaps it for a coconut with a straw as the young boy giggles with a friend. Similar to the spoonful posters, these red Xs visually mark salt and sugar as negative nutrients. The foods are thus rendered morally suspect and should be cut or replaced with local foods when possible.

The scientist also valorizes indigenous foods for their health values. In particular, he draws on Samoan epistemology that links starchy foods with strong bodies and in which strong households are synonymous with an abundance of taro. For example, Hardin's adopted father once whispered to her, "Samoan babies are stronger then palagi [white/European] babies," as they ate their evening meal. He was prompted to make this comparison because his daughter was just beginning to feed her son taro that she had masticated. The idea is that Samoan babies eat mea'a'ano, not palagi foods, and they are strong as a result. The son-in-law, noticing 
the commentary his father-in-law was providing, said, "The baby will be a rugby player. So he needs to eat his taro to become strong." Imported baby food is considered weak food; it is not food that babies need to become lapo'a (fat) and malosi (strong). Taro is a material substance par excellence for making claims about people and place that clearly link indigenous strength with taro and European weakness with some foreign foods (see also Pollock I992, 2000; Kahn I988).

The video takes this indigenous connection between power and strength derived from taro and extends it to fruits and vegetables. The scientist hands a young girl and boy an avocado, saying, "If you like drinking tea and eat bread, change now your butter to avocado. You have power." He again encourages the viewer to replace high-fat negative nutrients, like butter, with local alternatives. Then, another teen boy appears, carrying an amo (pole) with a basket of taro and a bushel of bananas hanging from each side, indexing masculine plantation work. The scientist rhymes in Samoan: "Vegetables and fruits, and that boy taro. You won't have any more sickness, but emerging is the muscle," as the young man lifts the amo like a barbell. Similarly, in a meme that was circulating within Hardin and Kwauk's networks on Facebook, Samoan feau (chores) were linked to exercise, equating the labor of plantations with weight lifting in gyms. The meme showed two young men carrying coconut husks mounted to an amo, again linking a Samoan everyday planation technology with exercise equipment.

News media have also assigned value to local foods based on the validation of nutritional science. The Samoa Observer has regularly reprinted articles from around the world focused on the scientific analysis of local staples. Headlines read: "Benefits of the Papaya," "Experts Back Medical Benefits of Coconut," and "Coconut Oil Health Benefits" (20I2a, $20 \mathrm{I} 2 \mathrm{~b}, 20 \mathrm{I} 2 \mathrm{c})$. These stories reflect what local officials have endeavored to achieve: helping local farmers refocus their efforts on plantation foods. One story, titled "Focus on Local Food" (Addison 20II), quotes the director of research at the University of the South Pacific, a university associated with agricultural research in Sāmoa, saying, "We need to look at our food habits and focus back to the traditional Pacific foods." However, this looking back is reliant on root and tuber experts to help select "high yielding and better varieties of taro, cassava, sweet potato, and yams." Beyond news media, many local health professionals valorized local foods for their superior nutritional qualities compared to imported foods associated 
with health. For example, a local fitness instructor would sell coconuts and smoothies after her classes, which valorized local coconuts as superior to imported energy drinks. Local and indigenous foods were therefore valued based on scientific verification of their agricultural robustness and nutritional value.

From these myriad messages, health can be seen as a state of the body resulting from eating balanced (nutritional) foods and being active. It is a state achieved, worked on, and available to any individual through controlled consumption of negative nutrients and knowledge of nutrition. Fruits and vegetables are associated with the potential power of starches, which indigenous food categories tend to separate. By linking fruits and vegetables with Samoan notions of power, the special capacities of starches, and taro in particular, are extended to mea'ai paleni. In a broader sense, local foods are actively valorized because of their nutritional qualities, grounding value in scientific verification.

\section{ENDING WITH A QUESTION}

These health promotion materials permeate clinical settings across Sāmoa. They were so ever-present in our fieldwork-in the hospital, clinics, and agricultural offices-that we came to ignore them. Their pervasiveness enforces their authority, insisting that food categories are scientific and objective, though on closer inspection, food categories-good, bad, edible, inedible-are flexible and reflect how knowledge about the body, health, and community are produced. Public health efforts in Sāmoa to change diets have focused on meaning making as a way to influence behavioral change. These campaigns have attempted to provide new frameworks for interpreting both indigenous and local (but introduced) foods by drawing on scientific expertise, thereby shoring up nutritionism. We refer to this interpretive framework as elemental eating-that is, a reductive nutritional perspective that is supposed to guide eating that does not incorporate indigenous food values that revolve around the interconnections between food, land, and community. Importantly, this elemental eating valorizes indigenous foodways while also undermining related values. Elsewhere in the world, a return to "traditional" or indigenous foodways is embedded in broader political projects related to sovereignty, but in Sāmoa, public health officials are engaged in the selective valorization of culture by promoting a scientistic framework for interpreting nutrition and, therefore, value (see, for example, Grey and 
Patel 20I5; Bradley and Herrera 20I6; Hunt and Holmes 20I5; Matties 2016; Martens and others 20I6).

Attempting to align nutritional value with the cultural values of food raises political issues that reflect longer histories and legacies of colonialism. In some ways, these health promotion campaigns mirror emerging and intersecting movements in food justice and indigenous sovereignty from Toronto to Honolulu, where growing efforts to connect rising rates of cardiometabolic disorders with the colonial destruction of lifeways have given rise to the revitalization of indigenous food knowledge (Howard 20I4; Kimura and Suryanata 20I6; Wilson 20I6; MacRae 20I6). In doing so, many of the advocacy organizations associated with these movements hope to revitalize communities (Aikau and Camvel 20I6; Vaughan and Ayers 2016; Chollett 20I4; García 20I3). This cultural turn reflects broader movements in health that connect community vitality, resilience to historical violence, and individual embodied experience to localized notions of well-being (McMullin 2005, 2010; Richardson and others 20I9). Research at this intersection continuously shows that indigenous diets reduce risks associated with cardiometabolic disorders (Shintani and others I99I; see also Milburn 2004). In Sāmoa, this relationship between indigenous diets and health is reflected in the fact that rural communities tend to have lower rates of cardiometabolic disorders than urban populations (Hawley and others 20I4). However, rural living raises risks for other health problems and social suffering related to lack of national resources and cash poverty.

Indigenous researchers and activists have illustrated that eating and growing food are ways of knowing and therefore constitute an act of connecting with ancestors, as opposed to being strictly understandable through "the science of it" (Marshall 20I2, xx). In the context of Hawai'i, these studies show that "political mobilization is key to Native Hawaiian health, and a focus on health was clearly articulated as a critical arena of struggle within the sovereignty movement" (Marshall 20I2, 85). We have examined the interface of public health, food, and nutritional reductionism to think about valuation as action. This paper uses value as a framework for understanding how difference is both erased and highlighted through health promotion materials. In the end, we see that in health promotion, the sociality of food is reduced and made secondary, or nearly invisible, to nutritional value. We thus finish with a question for public health in Oceania: What are the tradeoffs of using scientific verification to valorize indigenous foodways? Could health promotion move beyond diet? 


\section{Notes}

I For more on the ways that food, land, and care are intimately involved with settler colonialism, see also Silva 2004, Kauanui 2018, Tengan 2008.

2 In the Pacific, foods like fruits and vegetables-what in Euro-American cultures would be considered part of a balanced meal-have not been considered components of a meal but rather a different category of foodstuff entirely, what Nancy Pollock called "non-meal edibles" (I985). Non-meal edibles, or "bonus" edibles, consist of the foods eaten throughout the day that are not considered real food, including snack foods like chips, afternoon tea with the occasional sandwich, and raw fruits, which are rarely eaten at a meal or as a meal. So, while fruits and vegetables are considered mea'ai (food), they are non-meal edibles and therefore conceived of as snacks and not required for main meals or feasting events (one exception is palusami, a dish of taro leaves cooked in coconut milk).

3 The response rate was 87 percent, resulting in a sample size of 659 respondents. Surveys were translated into Samoan, checked, revised, and back translated for accuracy by a Samoan government official. Basic statistical analysis was performed on survey data after responses were translated, coded, and organized in Microsoft Excel.

4 The most popular starch listed was taro, followed by fa'i (boiled or baked green bananas).

5 The most popular fruit and vegetable items named were papaya and coconut (usually the meaty flesh of a young coconut).

6 Of the seafood, fish was most widely cited; a small percentage listed imported chicken, then moasāmoa (Samoan chicken-local but thought to be lean and tough), and finally mutton flaps.

\section{References}

Addison, Brooke

20 I $\quad$ Coconut Oil Health Benefits. Samoa Observer, November I 2.

Aikau, Hōkūlani K, and Donna Ann Kameha'ikū Camvel

2016 Cultural Traditions and Food: Kānaka Maoli and the Production of Poi in the He'e'ia Wetland. Food, Culture \& Society I9 (3): 539$56 \mathrm{I}$.

Anderson, Warwick

2006 Colonial Pathologies: American Tropical Medicine, Race, and Hygiene in the Philippines. Durham, NC: Duke University Press.

Bell, Kristen, Darlene McNaughton, and Amy Salmon

20I I Alcohol, Tobacco and Obesity: Morality, Mortality and the New Public Health. New York: Routledge. 
Biltekoff, Charlotte

2013 Eating Right in America: The Cultural Politics of Food and Health. Durham, NC: Duke University Press.

Bradley, Katharine, and Hank Herrera

2016 Decolonizing Food Justice: Naming, Resisting, and Researching Colonizing Forces in the Movement. Antipode 48 (I): 97-I I 4.

Brewis, Alexandra A

20I I Obesity: Cultural and Biocultural Perspectives. New Brunswick, NJ: Rutgers University Press.

Chollett, Donna L

2014 The Native American Organic Garden: Using Service Learning as a Site of Resistance. Culture, Agriculture, Food and Environment 36 (2): 93-IO4.

Choy, Courtney C, Mayur M Desai, Jennifer J Park, Elizabeth A Frame, Avery A Thompson, Take Naseri, Muagututia S Reupena, Rachel L Duckham, Nicole C Deziel, and Nicola L Hawley

20I7 Child, Maternal and Household-Level Correlates of Nutritional Status: A Cross-Sectional Study among Young Samoan Children. Public Health Nutrition 20 (7): I 23 5-I 247.

Dumit, Joseph

2012 Drugs for Life: How Pharmacentical Companies Define Our Health. Durham, NC: Duke University Press.

Errington, Frederick, Tatsuro Fujikura, and Deborah Gewertz

2012 Instant Noodles as an Antifriction Device: Making the вор with PрP in PNG. American Anthropologist I I 4 (I): I9-3 I.

2013 The Noodle Narratives: The Global Rise of an Industrial Food into the Twenty-First Century. Berkeley, CA: University of California Press.

Errington, Frederick, and Deborah Gewertz

2008 Pacific Island Gastrologies: Following the Flaps. Journal of the Royal Anthropological Institute I4 (3): 590-608.

Fazzino II, David V, and Philip A Loring

2OI3 Nutritional and Cultural Transitions in Alaska Native Food Systems: Legacies of Colonialism, Contested Innovation, and Rural-Urban Linkages. In Doing Nutrition Differently: Critical Approaches to Diet and Dietary Intervention, edited by Allison Hayes-Conroy and Jessica Hayes-Conroy, 99-I Io. Farnham, Uk: Routledge.

Farmer, Paul, Jim Yong Kim, Arthur Kleinman, and Matthew Basilico, editors 20I3 Reimaging Global Health: An Introduction. Berkeley, CA: University of California Press. 
Farrell, Penny, Anne Marie Thow, Suzie Schuster, Pavle Vizintin, and Joel Negin 2019 Access to a Nutritious Diet in Samoa: Local Insights. Ecology of Food and Nutrition (April): I-I8.

Fee, Margery

2006 Racializing Narratives: Obesity, Diabetes and the "Aboriginal" Thrifty Genotype. Social Science \& Medicine 62 (I 2): 2988-2997.

Ferry, Elizabeth Emma

2005 Not Ours Alone: Patrimony, Value, and Collectivity in Contemporary Mexico. New York: Columbia University Press.

Field, Michael

2012 Samoa's Poor Are "Lazy": PM. Stuff.co, 24 January. http://www.stuff .co.nz/world/6305942/Samoa-s-poor-are-lazy-PM [accessed 27 Feb 20I9]

Finucane, Mariel M, Gretchen A Stevens, Melanie J Cowan, Goodarz Danaei, John K Lin, Christopher J Paciorek, Gitanjali M Singh, Hialy R Gutierrez, Yuan Lu, Adil N Bahalim, Farshad Farzadfar, Leanne M Riley, and Majid Ezzati

20I I National, Regional, and Global Trends in Body Mass Index since I980: Systematic Analysis of Health Examination Surveys and Epidemiological Studies with 960 Country-Years and 9.I Million Participants. Lancet 377 (9765): 557-567.

Gálvez, Alyshia

2018 Eating Nafta: Trade, Food Policies, and the Destruction of Mexico. Berkeley, ca: University of California Press.

García, María Elena

2013 The Taste of Conquest: Colonialism, Cosmopolitics, and the Dark Side of Peru's Gastronomic Boom. The Journal of Latin American and Caribbean Anthropology I 8 (3): 505-524.

Garro, Linda

2010 Beyond the Reproduction of Official Accounts: Parental Accounts Concerning Health and the Daily Life of a California Family. Medical Anthropology Quarterly 24 (4): 472-499.

Gewertz, Deborah, and Frederick Errington

2007 The Alimentary Forms of the Global Life: The Pacific Island Trade in Lamb and Mutton Flaps. American Anthropologist Io9 (3): 496508 .

2010 Cheap Meat: Flap Food Nations in the Pacific Islands. Berkeley, CA: University of California Press.

Goldberg-Hiller, Jonathan, and Noenoe K Silva

2015 The Botany of Emergence: Kanaka Ontology and Biocolonialism in Hawai'i. Native American and Indigenous Studies 2 (2): I-26.

Grey, Sam, and Raj Patel

2015 Food Sovereignty as Decolonization: Some Contributions from 
Indigenous Movements to Food System and Development Politics. Agriculture and Human Values 32 (3): 43 I-444.

Guthman, Julie

20I I Weighing In: Obesity, Food Justice, and the Limits of Capitalism. Berkeley, ca: University of California Press.

Hahn, Robert A, and Marcia C Inhorn

2008 Anthropology and Public Health: Bridging Differences in Culture and Society. New York: Oxford University Press.

Hardin, Jessica

2OI 5 Everyday Translation: Health Practitioners' Perspectives on Obesity and Metabolic Disorders in Samoa. Critical Public Health 25 (2): I $25-$ I 38 .

2019 Faith and the Pursuit of Health: Cardiometabolic Disorders in Samoa. Health, Inequality, and Social Justice. New Brunswick, NJ: Rutgers University Press.

Hardin, Jessica, and Christina Ting Kwauk

2OI 5 Producing Markets, Producing People: Local Food, Financial Prosperity and Health in Samoa. Food, Culture \& Society I 8 (3): 519539.

Hardin, Jessica, Amy McLennan, and Alexandra Brewis

2018 Body Size, Body Norms and Some Unintended Consequences of Obesity Intervention in the Pacific Islands. In Human Biology in the Pacific, edited by Nicola Hawley and Stephen McGarvey. Special issue of Annals of Human Biology 45 (3): 285-294

Hawley, Nicola L, Ryan L Minster, Daniel E Weeks, Satupaitea Viali, Muagututia Sefuiva Reupena, Guangyun Sun, Hong Cheng, Ranjan Deka, and Stephen T McGarvey

20I4 Prevalence of Adiposity and Associated Cardiometabolic Risk Factors in the Samoan Genome-Wide Association Study. American Journal of Human Biology 26 (4): 49I-50I.

Hayes-Conroy, Allison, and Jessica Hayes-Conroy

2OI3 Doing Nutrition Differently: Critical Approaches to Diet and Dietary Intervention. Farnham, uk: Routledge.

Hereniko, Vilsoni

I995 Woven Gods: Female Clowns and Power in Rotuma. Pacific Islands Monograph Series I 2. Honolulu: Center for Pacific Islands Studies and University of Hawai'i Press.

I999 Clowning as Political Commentary: Polynesia-Then and Now. In Art and Performance in Oceania, edited by Barry Craig, Bernie Kernot, and Christopher Anderson, I 5-27. Honolulu: University of Hawai'i Press. First published in The Contemporary Pacific 6 (I): I-28 (I994). 
Hite, Adele, Richard David Feinman, Gabriel E Guzman, Morton Satin, Pamela A Schoenfeld, and Richard J Wood

2010 In the Face of Contradictory Evidence: Report of the Dietary Guidelines for Americans Committee. Nutrition 26 (I0): 91 5-924.

Hobart, Hi'ilei Julia

2016a "Local": Contextualizing Hawai'i’s Foodways. Food, Culture \& Society I9 (3): 427-435.

2016b Snowy Mountaineers and Soda Waters: Honolulu and Its Age of Ice Importation. Food, Culture \& Society I9 (3): 46I-483.

2017 A "Queer-Looking Compound": Race, Abjection, and the Politics of Hawaiian Poi. Global Food History 3 (2): I33-I 49.

Hobart, Hi'ilei Julia, editor

2018 The Foodways of Hawai $i$ : Past and Present. New York: Routledge.

Howard, Heather A

2014 Canadian Residential Schools and Urban Indigenous Knowledge Production about Diabetes. Medical Anthropology 33 (6): 529-545.

2018 Settler Colonial Biogovernance and the Logic of a Surgical Cure for Diabetes. American Anthropologist I 20 (4): 81 7-822.

Hunt, Sarah, and Cindy Holmes

2015 Everyday Decolonization: Living a Decolonizing Queer Politics. Journal of Lesbian Studies I9 (2): I 54-I72.

Kahn, Miriam

I986 Always Hungry, Never Greedy: Food and the Expression of Gender in a Melanesian Society. Long Grove, CA: Waveland Press.

I988 “Men Are Taro" (They Cannot Be Rice): Political Aspects of Food Choices in Wamira, Papua New Guinea. Food \& Foodways 3 (I-2): $4 \mathrm{I}-57$.

Kauanui, J Kēhaulani

2018 Paradoxes of Hawaiian Sovereignty: Land, Sex, and the Colonial Politics of State Nationalism. Durham, NC: Duke University Press.

Keighley, Ember D, Stephen T McGarvey, Christine Quested, Charles McCuddin, Satupaitea Viali, and Uto'ofili A Maga

2007 Nutrition and Health in Modernizing Samoans: Temporal Trends and Adaptive Perspectives. In Health Changes in the Asia-Pacific Region: Biocultural and Epidemiological Approaches, edited by Ryutaro Ohtsuka and Stanley J Ulijaszek, I47-I9I. Cambridge, UK: Cambridge University Press.

Kimura, Aya Hirata, and Krisnawati Suryanata, editors

2016 Food and Power in Hawai ${ }^{\circ} i$ : Visions of Food Democracy. Honolulu: University of Hawai'i Press. 
Kirkland, Anna

20I I The Environmental Account of Obesity: A Case for Feminist Skepticism. Signs $36(2): 463-486$.

Landecker, Hannah

20I I Food as Exposure: Nutritional Epigenetics and the New Metabolism. Biosocieties 6 (2): 167-194.

Linnekin, Jocelyn

I99I Fine Mats and Money: Contending Exchange Paradigms in Colonial Samoa. Anthropological Quarterly 64 (I): I-I3.

MacRae, Graeme

2016 Food Sovereignty and the Anthropology of Food: Ethnographic Approaches to Policy and Practice. In Food Sovereignty and the Anthropology of Food: Ethnographic Approaches to Policy and Practice, edited by Graeme MacRae. Special issue of Anthropological Forum 26 (3): 227-232.

Manderson, Lenore

2008 Anthropological Perspectives on the Health Transition. In International Encyclopedia of Public Health, second edition, I22-I 28. Oxford: Academic Press.

Marshall, Wende Elizabeth

$20 \mathrm{I}$ Potent Mana: Lessons in Power and Healing. Albany, NY: SunY Press.

Martens, Tabitha, Jaime Cidro, Michael Anthony Hart, and Stéphane McLachlan 2016 Understanding Indigenous Food Sovereignty through an Indigenous Research Paradigm. Journal of Indigenous Social Development 5 (I): I $8-37$.

Matties, Zoe

2016 Unsettling Settler Food Movements: Food Sovereignty and Decolonization in Canada. Cuizine: The Journal of Canadian Food Cultures/ Cuizine: Revue Des Cultures Culinaires Au Canada 7 (2). Available

McMullin, Juliet at https://doi.org/I0.7202/IO38478ar

2005 The Call to Life: Revitalizing a Healthy Hawaiian Identity. Social Science \& Medicine 6I (4): 809-820.

2010 The Healthy Ancestor: Embodied Inequality and the Revitalization of Native Hawaiian Health. Walnut Creek, CA: Left Coast Press.

Milburn, Michael P

2004 Indigenous Nutrition: Using Traditional Food Knowledge to Solve Contemporary Health Problems. The American Indian Quarterly 28 (3/4): 4I I-434.

Miller, Daniel 2008 The Uses of Value. Geoforum 39 (3): I I 22-II32. 
Ministry of Health Samoa

20 Io National Health Promotion Policy 20ı-2015. Apia, Sāmoa: Policy Unit, Strategic Development and Planning Division.

Mitchell, William E, editor

I992 Clowning as Critical Practice: Performance Humor in the South Pacific. Pittsburgh, PA: University of Pittsburgh Press.

Mol, Annemarie, Ingunn Moser, and Jeannette Pols, editors

2010 Care in Practice: On Tinkering in Clinics, Homes and Farms. Bielefeld, Germany: transcript Verlag.

Montoya, Michael

2007 Bioethnic Conscription: Genes, Race, and Mexicana/o Ethnicity in Diabetes Research. Cultural Anthropology 22 (I): 94-I 28.

NCD Risk Factor Collaboration

2016 Trends in Adult Body-Mass Index in 200 Countries from I975 to 20I4: A Pooled Analysis of r698 Population-Based Measurement Studies with I9.2 Million Participants. Lancet 387 (I0026): I377I396.

Nestle, Marion

2007 Food Politics: How the Food Industry Influences Nutrition and Health. Berkeley, cA: University of California Press.

Nihill, Michael

$200 \mathrm{I}$ Not Feasting with Friends: The Meaning of Meat in Anganen. Oceania $7 \mathrm{I}(4): 265-278$.

Paxson, Heather

2012 The Life of Cheese: Crafting Food and Value in America. Berkeley, CA: University of California Press.

Petersen, Alan, and Deborah Lupton

I996 The New Public Health: Health and Self in the Age of Risk. London: Sage.

Petryna, Adriana

2002 Life Exposed: Biological Citizens after Chernobyl. Princeton, NJ: Princeton University Press.

Plahe, Jagjit Kaur, Shona Hawkes, and Sunil Ponnamperuma

2013 The Corporate Food Regime and Food Sovereignty in the Pacific Islands. The Contemporary Pacific 25 (2): 309-338.

Pollock, Nancy

I985 The Concept of Food in a Pacific Society: A Fijian Example. Ecology of Food and Nutrition I 7:195-203.

I992 These Roots Remain: Food Habits in Islands of the Central and Eastern Pacific Since Western Contact. Laie, HI: Institute for Polynesian Studies.

2000 Taro. In Cambridge World History of Food, edited by Kenneth F 
Kiple and Kriemhild Coneè Ornelas, 218-230. New York: Cambridge University Press.

Porter, Theodore M

I995 Trust in Numbers: The Pursuit of Objectivity in Science and Public Life. Princeton, NJ: Princeton University Press.

Richardson, Emma, Emma Hughes, Sharon McLennan, and Litea Meo-Sewabu 20I9 Indigenous Well-Being and Development: Connections to Large-Scale Mining and Tourism in the Pacific. The Contemporary Pacific 3 I (I): I-34.

Rose, Nikolas, and Carlos Novas

2005 Biological Citizenship. In Global Assemblages: Technology, Politics, and Ethics as Anthropological Problems, edited by Aihwa Ong and Stephen J Collier, 439-463. Malden, MA: Blackwell.

Rubin, Lisa R, and Jessica A Joseph 20I3 An Ounce of Prevention Is Worth a Ton of Controversy: Exploring Tensions in the Fields of Obesity and Eating Disorder Prevention. In Reconstructing Obesity Research: The Meaning of Measures and the Measures of Meaning, edited by Megan McCullough and Jessica Hardin, I99-2I4. New York: Berghahn Books.

Saldaña-Tejeda, Abril, and Peter Wade 20I 8 Obesity, Race and the Indigenous Origins of Health Risks among Mexican Mestizos. Ethnic and Racial Studies 4I (I 5): 273 I-2749.

Samoa Observer

20I 2a Benefits of the Papaya. 7 January.

2OI 2b Experts Back Medical Benefits of Coconut. 23 September.

20I2c Focus on Local Food. 25 April.

Sanabria, Emilia

2016 Circulating Ignorance: Complexity and Agnogenesis in the Obesity "Epidemic." Cultural Anthropology 3 I (I): I3 I-I 58.

Sanabria, Emilia, and Emily Yates-Doerr

20I 5 Alimentary Uncertainties: From Contested Evidence to Policy. BioSocieties IO (2): II7-I 24 .

Schoeffel, Penelope

I984 Dilemmas of Modernization in Primary Health Care in Western Samoa. Social Science \& Medicine I9 (3): 209-2 I 6.

Schram, Ryan

201 8 Harvests, Feasts, and Graves: Postcultural Consciousness in Contemporary Papua New Guinea. Ithaca, NY: Cornell University Press.

Scrinis, Gyorgy

2008 On the Ideology of Nutritionism. Gastronomica: The Journal of Critical Food Studies 8 (I): 39-48. 
Shintani, T T, C K Hughes, S Beckham, and H K O’Connor

I99I Obesity and Cardiovascular Risk Intervention through the Ad Libitum Feeding of Traditional Hawaiian Diet. The American Journal of

Silva, Noenoe K Clinical Nutrition 53 (6): I647S-165IS.

2004 Aloha Betrayed: Native Hawaiian Resistance to American Colonialism. Durham, NC: Duke University Press.

Sinavaiana, Caroline

I992 Comic Theater in Samoa as Indigenous Media. Pacific Studies I 5 (4): I99-209.

Singer, Merrill

20I4 Following the Turkey Tails: Neoliberal Globalization and the Political Ecology of Health. Journal of Political Ecology 2I (I): 436-45 I.

Teaiwa, Katerina Martina

2007 South Asia Down Under: Popular Kinship in Oceania. Cultural Dynamics I9 (2-3): I93-232.

Tengan, Ty P Kāwika

2008 Native Men Remade: Gender and Nation in Contemporary Hawai ${ }^{\circ} i$. Durham, NC: Duke University Press.

Thow, A, P Heywood, J Schultz, C Quested, S Jan, and S Colagiuri

20I I Trade and the Nutrition Transition: Strengthening Policy for Health

Valdez, Natali in the Pacific. Ecology of Food and Nutrition 50 (I): I8-42.

2018 The Redistribution of Reproductive Responsibility: On the Epigenetics of "Environment" in Prenatal Interventions. Medical Anthropology Quarterly 32 (3): 425-442.

Vaughan, Mehana Blaich, and Adam L Ayers

2016 Customary Access: Sustaining Local Control of Fishing and Food on Kaua'i's North Shore. Food, Culture \& Society I9 (3): 5 I7-538.

Warin, Megan

2015 Material Feminism, Obesity Science and the Limits of Discursive Critique. Body \& Society 2 I (4): 48-76.

Warin, Megan, Vivienne Moore, Michael Davies, and Stanley Ulijaszek

2016 Epigenetics and Obesity: The Reproduction of Habitus through Intracellular and Social Environments. Body \& Society 22 (4): 53-78.

Weiss, Brad

2013 Food: Integration. Fieldsites, 26 August. Available on the Society for Cultural Anthropology website: https://culanth.org/fieldsights/food -integration [accessed 25 Jan 20I9]

2016 Real Pigs: Shifting Values in the Field of Local Pork. Durham, NC: Duke University Press.

Wilson, Marisa

2016 Postcolonialism, Indigeneity and Struggles for Food Sovereignty: 
Alternative Food Networks in Subaltern Spaces. New York: Routledge.

Yates-Doerr, Emily

2012 The Opacity of Reduction: Nutritional Black-Boxing and the Meanings of Nourishment. Food, Culture \& Society I 5 (2): 293-3 I 3.

2015 The Weight of Obesity: Hunger and Global Health in Postwar Guatemala. Berkeley, cA: University of California Press.

20I8 Strategic Reductionism: Complexity, Inequality, and the Challenge of "Doing Good" Science in Global Health. Presented as part of the Anthropology@ Work series, Pacific University, Forest Grove, Oregon, 2 November.

20I9 Whose Global? Which Health? Unsettling Collaboration Through Careful Equivocation. American Anthropologist I2 I (2): 297-3 IO.

Young, Michael W

I97I Fighting with Food: Leadership, Values and Social Control in a Massim Society. New York: Cambridge University Press.

\section{Abstract}

In this article, we suggest that indigenous foods are valorized and expanded through their re-signification as nutritious in Samoan health promotion campaigns. These campaigns elucidate how public health selectively values culture while extending the category of indigenous food to include non-autochthonous fruits and vegetables, in turn reshaping meanings associated with indigenous foods in relation to health. We first present material that demonstrates the impact of health promotion materials on food knowledge. We then highlight how nutrition as a value dominates official accounts and explore health promotion tools that have encouraged audiences to deconstruct food into constitutive parts, particularly negative nutrients like fat and salt. We call this "elemental eating," which mutes the distinction between imported, new foods and indigenous, local foods by foregrounding nutritional components. Finally, we examine a recent media campaign that presented a new food category, mea'ai paleni, as a hybrid of indigenous and local foods. Health promotion in this context revalues indigenous foods, broadening the category by promoting a scientistic framework for understanding nutrition. This interpretive framework reorganizes food categories from strictly new, imported foods and local, indigenous foods to healthy and unhealthy foods, reflecting epidemic discourses in both local media and scholarship while also complicating the typical epidemiological representation of the nutrition transition.

KEYWORDS: health promotion, Sāmoa, food, value, public health, nutrition 